\title{
A congenital intraspinal gastroenterogenous cyst in diastematomyelia
}

\author{
PATRICIA M. BALE \\ From the Institute of Pathology, Royal Alexandra Hospital for Children, \\ Camperdown, Sydney, N.S.W., 2050, Australia
}

SUMMARY A female neonate, with neurological signs and leucocytosis in sterile spinal fluid, was found to have anomalies of the upper thoracic vertebral bodies with a bony spur indicating diastematomyelia. The spur was removed, but symptoms recurred. Necropsy at the age of 5 months revealed an intraspinal gastroenterogenous cyst containing a perforated peptic ulcer. Analysis of eight previous reports of intraspinal enterogenous cysts, shows that, like prevertebral enterogenous cysts, they are frequently combined with defects in the vertebral bodies. This association suggests development from an embryonic ectoendodermal adhesion. Vertebral body defects are a significant pointer to the diagnosis and should not be overlooked, as curative resection is sometimes possible.

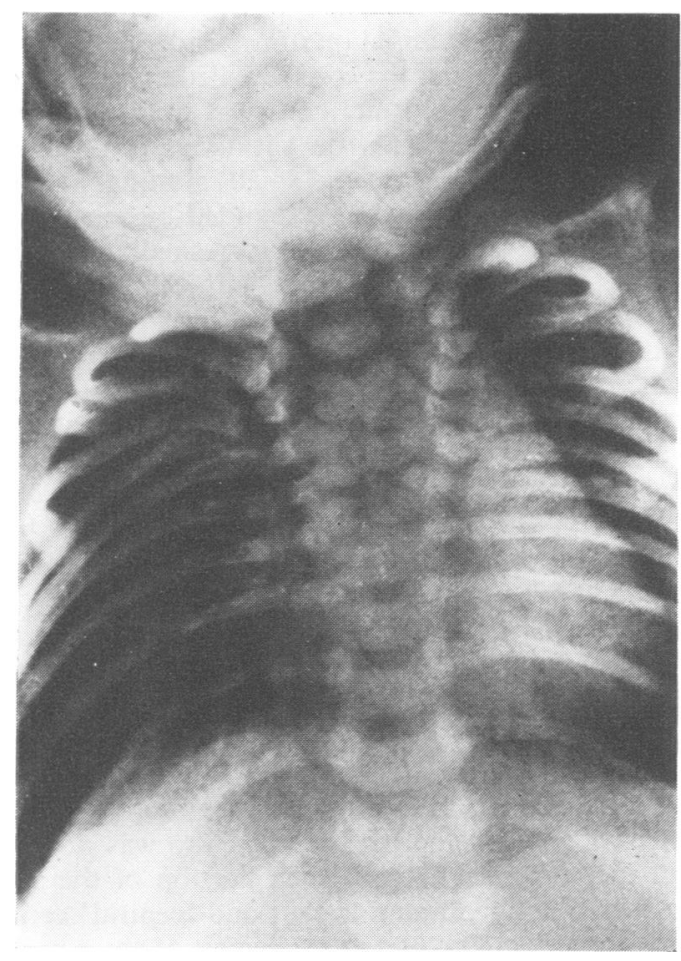

FIG. 1. The spine shows widening of the upper thoracic vertebral canal, butterfly vertebrae, hemivertebrae, and a faint midline bony spur (T3-T4).
The vertebral canal is a rare site for enterogenous cysts and only eight well-documented cases have been found. They have been recorded under a variety of names, including foregut cyst, gastrocystoma, neurenteric cyst, and teratoma. Not only is the terminology confusing, but the histogenesis has been disputed.

The present report describes a case of intraspinal gastroenterogenous cyst with vertebral body defects. This association supports the theory of origin from a developmental anomaly.

\section{CASE REPORT}

A baby girl who had been feeding poorly presented at the age of 6 days with irregular tremors of all limbs. Examination revealed an ill-looking infant with a slight skin indentation over the mid-thoracic region of the back, mildly hypotonic lower limbs, and an anaesthetic perineum. The fontanelle was soft. The cerebrospinal fluid contained 520 white blood cells $/ \mathrm{c} . \mathrm{mm}, 40 \%$ of which were neutrophils, but no organisms were isolated from any of the eight samples cultured during the first six weeks. The protein content was $100 \mathrm{mg} / 100 \mathrm{ml}$.

Radiographs revealed marked widening of the vertebral canal from T1 to T6 vertebrae and anomalies of the vertebral bodies including butterfly vertebrae (T3 and T4), hemivertebrae (T5 and T6), and a central defect extending from $\mathrm{T} 4$ to $\mathrm{T} 6$ 
vertebrae. In addition, at T3-T4 vertebrae a faint mid-line longitudinal density indicated a bony spur of diastematomyelia (Fig. 1). On myelography, the contrast medium in the upper thoracic region was seen to split into two columns, the left terminating abruptly, and the irregular right column was seen on the lateral view to be separated from the body of T4 vertebra by a filling defect interpreted as the bony spur.

At the age of 12 days a laminectomy was performed and the bony spur excised. At first the baby remained drowsy, with twitching of all limbs and an unstable temperature, and then at the age of 3 weeks the head circumference began to increase. However these signs abated and the infant was sent home. At the age of 4 months she was readmitted because she was irritable, feeding poorly, and had febrile episodes. She was found to have a tense fontanelle; needle ventriculography demonstrated dilated lateral

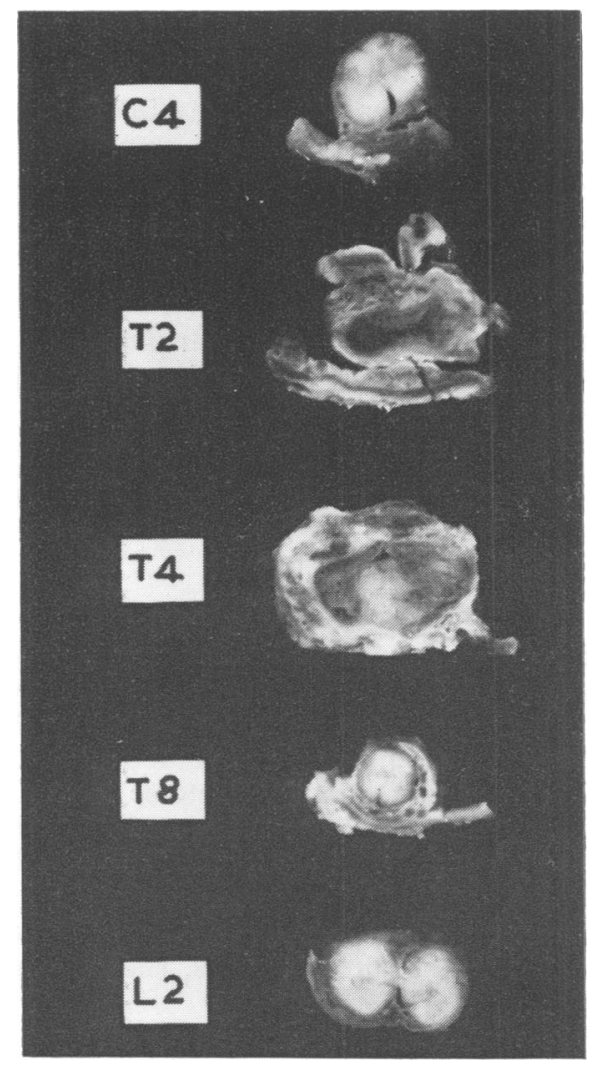

FIG. 2. Transverse blocks of the spinal cord, which is normal at C4 and T8 and split at L2. Enlargement at T2 and T4 is due to a thick-walled cyst. ventricles, and a ventriculoatrial shunt was performed. Postoperatively she developed respiratory problems and died $\mathbf{1 0}$ days after the procedure, at the age of $5 \frac{1}{2}$ months, with what was thought to be aspiration pneumonia.

PATHOLOGICAL FINDINGS At necropsy the major abnormalities were in the vertebral canal and lungs. A surgical scar extended from the level of C5 to $\Upsilon 6$ vertebrae. Beneath this there were dense fibrous adhesions between the very thickened tough, almost cartilaginous dura mater and the vertebral canal, leptomeninges, and spinal cord. There was a small intradural abscess beneath the middle of the scar, and the underlying spinal cord appeared swollen. Transverse slices of the spinal cord between the 2 nd to 5th thoracic segments showed what appeared to be a swollen misshapen cord (Fig. 2). In the block from the 4th thoracic segment a small crescentic cleft was seen posterior to a pale central area. No cyst was recognized. Above and below the affected thoracic segment, spinal cord of more normal architecture was identified, but in the lumbar region the cord was split into two portions contained in a singleo dural sheath (Fig. 2).

Microscopic examination of the 2nd, 3rd, and $4 \mathrm{th} \stackrel{\text { ? }}{\mathrm{D}}$ thoracic segments of the cord revealed that what haof appeared to be abnormal cord was in fact a thick 0 walled cyst. It had a narrow slit-like lumen with in foldings lined by gastric and small intestinal mucose (Fig. 3 and 4). This was surrounded by musculariš mucosae, submucosa with a few small lymphoid follicles, and a well-orientated double-layered muscularis propria containing ganglion cells. Embedded in the ventral wall of the cyst was a nodule of pancreatic tissue (Fig. 5) containing islets of Langerhans. Merging with the outer part of the cyst wall was a band of adipose tissue containing large blood vessels suggestive of intestinal mesentery. In one area a peptic ulcer in the small intestinal mucosa had perforated through the entire thickness of the cyst wall and the spinal cord (Fig. 6).

In the affected segments, the posteriorly displaced cord was represented merely by two flattened oval plates of neural tissue (Fig. 3 and 6) with an occasional large neurone. The medial part of each plate contained one or two irregular ependyma-lined 'central' canals. Immediately above and below the affected segment the cord architecture was normal, but in the lumbar region each portion of the split cord had its own anterior cleft and 'central' canal. However, each half had only one pair of nerve roots, and consequently the condition was interpreted as diastematomyelia rather than diplomyelia.

Inflammatory fibrosis in the spinal meninges extended beyond the affected segments to the upper 


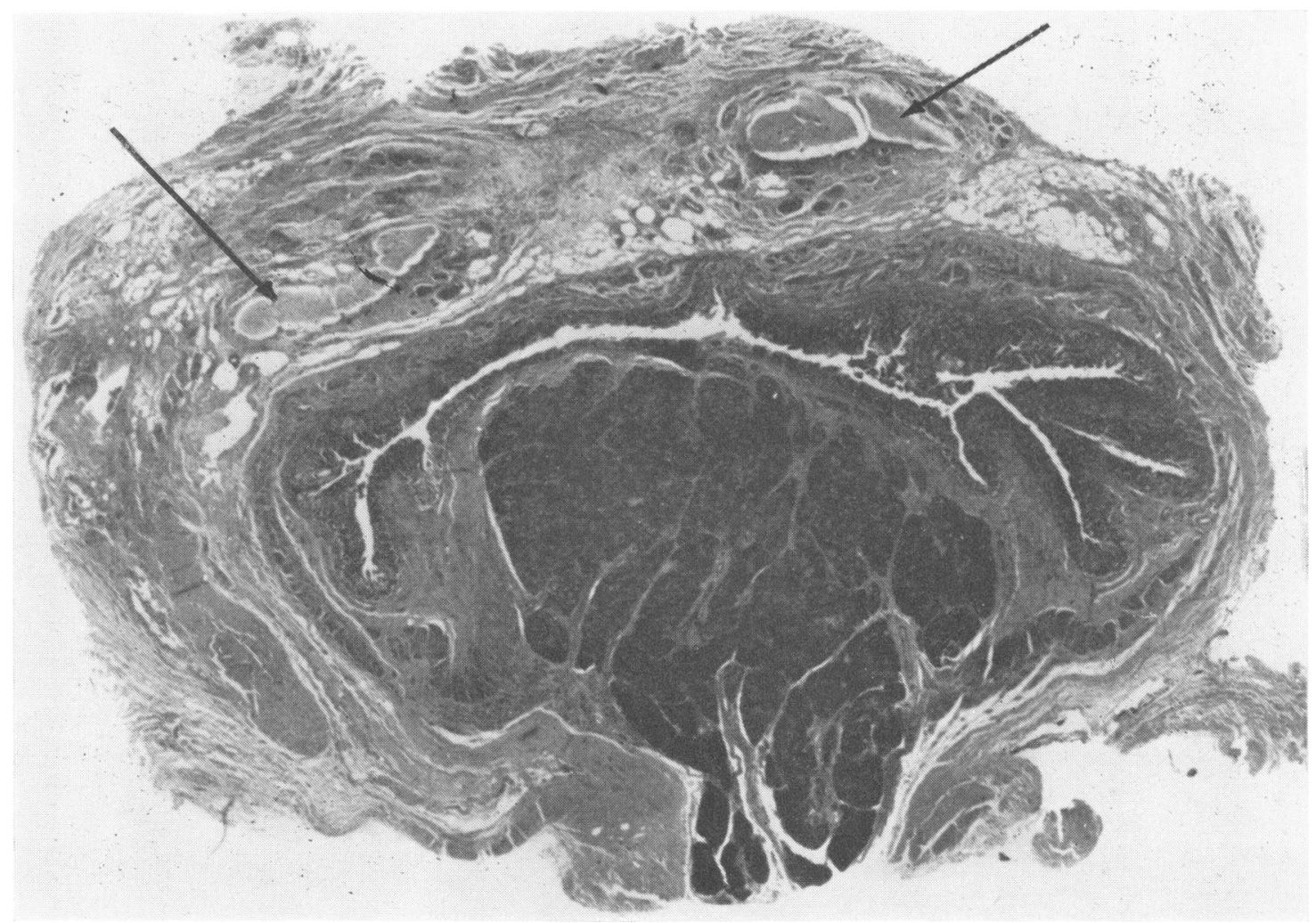

FIG. 3. Transverse section of cord at T4. The central branching horizontal cleft is the lumen of the cyst. Below this is the nodule of pancreas and, above, the spinal cord (arrows).

cervical region and there was a fibrino-purulent exudate over the base of the brain. The distal end of the ventriculoatrial shunt tube was lightly attached to the wall of the right atrium by a vegetation of bacterial endocarditis. Several pulmonary arteries were occluded by fibrin and white cell thrombi, and multiple small abscesses were present in the lungs. Staphylococcus aureus was cultured from these, and from the intradural abscess.

Additional findings were left hydro-ureter and mild focal left renal dysplasia. No mediastinal or abdominal enterogenous cyst was found.

\section{DISCUSSION}

An enterogenous cyst is a cystic duplication of the foregut composed of mucosa, submucosa, and well-oriented muscularis propria. The lining varies from small intestinal to gastric or oesophageal mucosa, and the latter includes not only stratified squamous but also ciliated columnar epithelium as in the fetal oesophagus. A nodule of pancreatic tissue may be present, or a peptic ulcer which may perforate. The intraspinal cyst described showed all of these features, and eight documented examples have been found in the literature. Additional probable cases with inadequate pathological data for assessment were reported by Neuhauser et al. (1958), Small (1962), and Langmaid and Jones (1963). A closely related lesion, a diverticulum from the oesophagus to the cervical arachnoid, was recorded by Rhaney and Barclay (1959, case 2$)$.

Of the nine detailed cases now available (Table), seven occurred in infants and two in young adults. All were situated in the cervical or thoracic region and most were ventral to the spinal cord. Three were intramedullary, between the two parts of a split spinal cord. Two previous cysts contained gastric mucosa, and one of these showed an ulcer which had already per- 


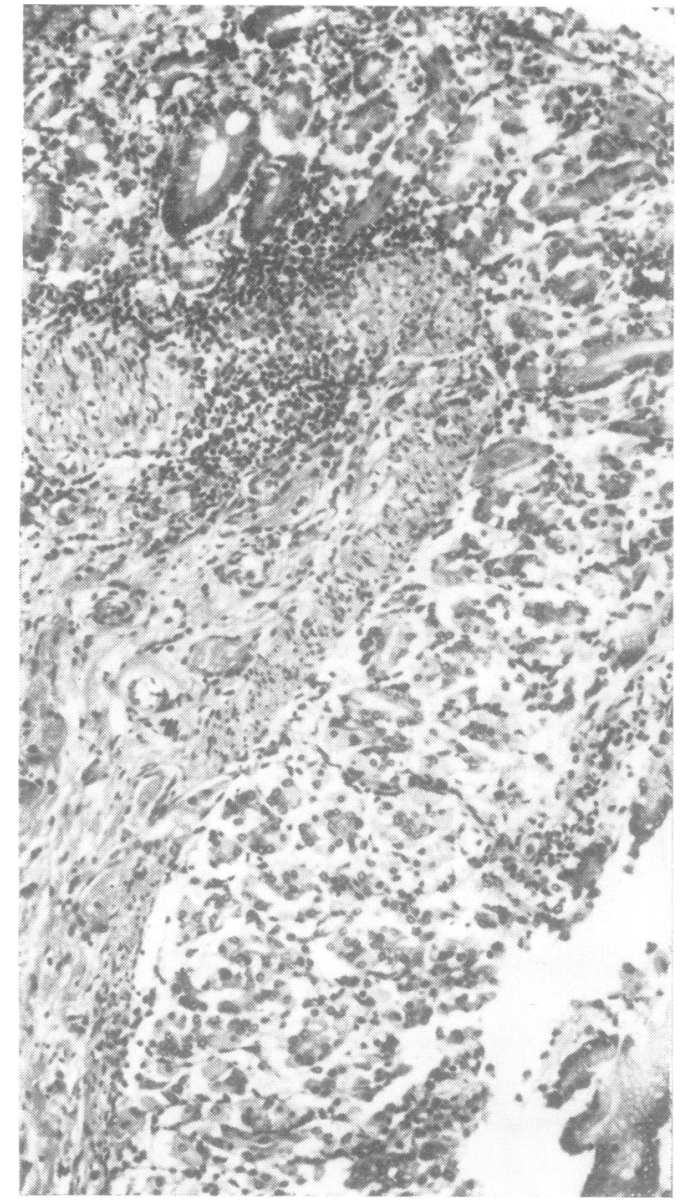

FIG. 4. Part of the cyst lining, showing gastric mucosa with muscularis mucosae. $H$ and $E, \times 40$.

forated at the age of 1 day (Rhaney and Barclay, 1959). The three oldest patients recovered after resection of the cyst, two died after unsuccessful surgery, and four were diagnosed only at necropsy.

The most common intraspinal cysts are extradural cystic herniations of arachnoid and dermoid cysts (Rand and Rand, 1960).

Intradural cysts are uncommon, and may be thick or thin walled. Thick walled cysts are usually enterogenous, although the variety of tissues sometimes present has led certain authors to regard them as cystic teratomas (Puussepp, 1934; Cameron, 1957). The adipose tissue,

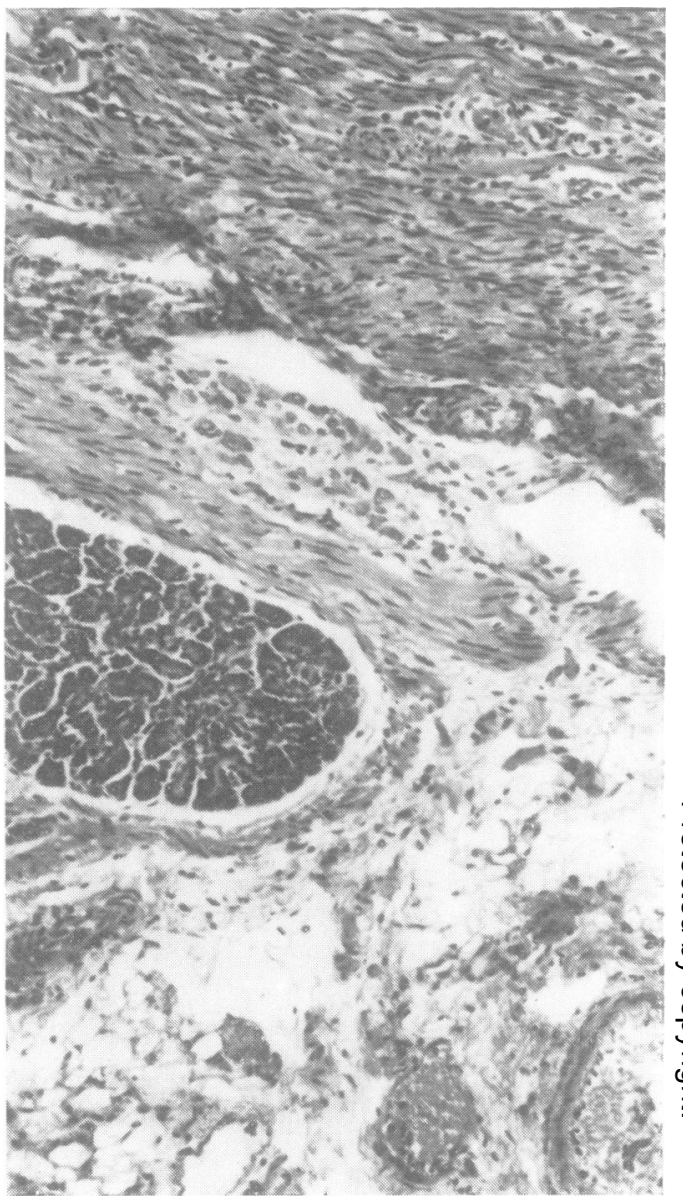

FIG. 5. Outer part of cyst wall, showing smooth muscle, myenteric plexus, pancreatic tissue, adipose tissue, and vessels. $H$ and $E, \times 32$.

vessels, and nerves often described may well represent intestinal mesentery. However, occasional convincing examples of true teratomas have been reported (Harrington and Kell, 1955).

Thin-walled translucent intradural cysts are $\frac{0}{}$ usually lined by a single layer of cuboidal or 3 . columnar epithelium surrounded by only a thin 8 fibrous membrane. They have been variously termed 'teratomatous' cysts (Hoefnagel et al., 욱 1962), ependymal cysts (Moore and Book, 1964), $\rightarrow$ and even enterogenous cysts (Harriman, 1958; Adams and Castleman, 1960; Scoville et al., N 1963), although histological criteria for the latter $N$ were absent. Some intradural cysts, probably of N 


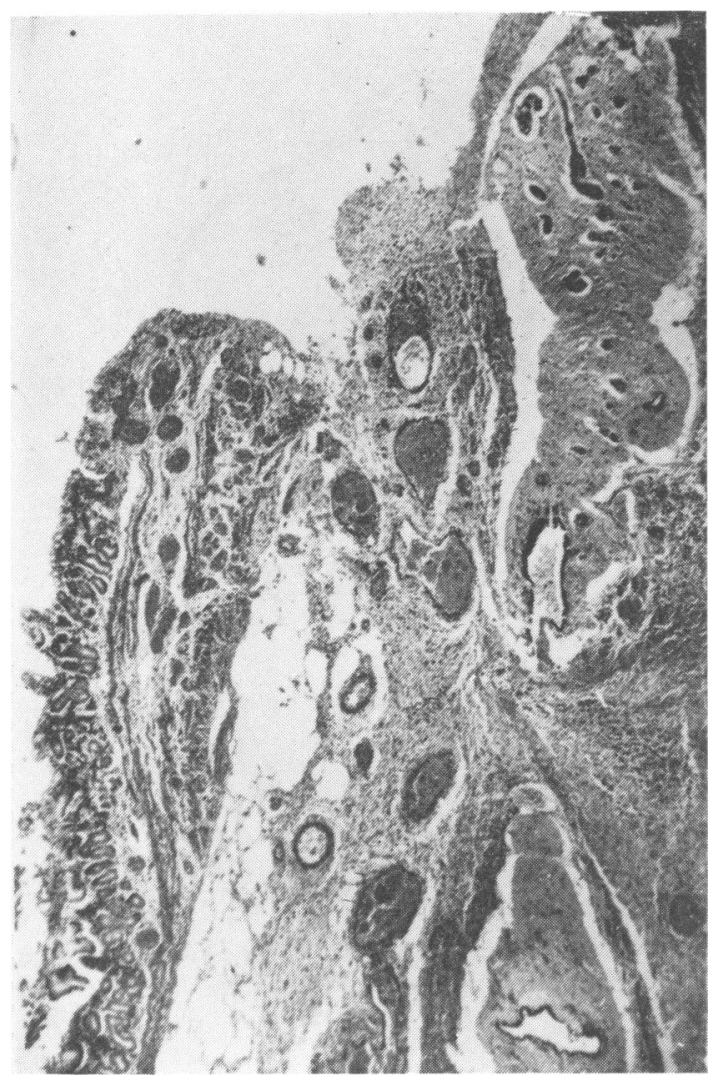

foregut origin, are partly thin walled with a nodular thickening containing mucous glands and cartilage, and resemble bronchogenic cysts (Kubie and Fulton, 1928; Bucy and Buchanan, 1935). Others are not easily categorized (Masten, 1940).

Thick and thin-walled cysts differ also in their position and associated bone changes. Rewcastle and Francoeur (1964) have pointed out that the thin-walled 'teratomatous' cysts are usually situated dorsal to the spinal cord and any bone changes are merely secondary to pressure. On the other hand thick-walled enterogenous cysts are more often ventral to the cord and associated with vertebral body defects. Both types of cyst may be combined with posterior spina bifida and myelomeningocele.

The present case, like most of the reported examples of intraspinal enterogenous cyst where adequate radiological or postmortem examination was performed, was associated with defects in the vertebral bodies (Korff, 1937; Knight et

FIG. 6. Perforated ulcer, with inflammatory exudate extending from small intestinal mucosa (left), to the flattened plates of spinal cord (right) each with an ependyma-lined canal. $H$ and $E, \times 10$.

TABLE

INTRASPINAL FOREGUT CYSTS

\begin{tabular}{|c|c|c|c|c|c|c|c|}
\hline Author & Sex & Age & Site & Histology & $\begin{array}{l}\text { Treatment } \\
\text { outcome }\end{array}$ & $\begin{array}{l}\text { Vertebral } \\
\text { anomalies }\end{array}$ & $\begin{array}{l}\text { Associated } \\
\text { lesion }\end{array}$ \\
\hline Puuss $2 p p$ (1934) & $\mathbf{M}$ & $27 \mathrm{yr}$ & C3 -4 & $\begin{array}{l}\text { ? Enterogenous } \\
\text { ? Oesophageal }\end{array}$ & $\begin{array}{l}\text { Resection. } \\
\text { Alive }\end{array}$ & - & Nil \\
\hline Korff (1937) & $\mathbf{F}$ & 8 days & $\begin{array}{l}\text { Low T } \\
\text { IM* }\end{array}$ & Enterogenous & $\begin{array}{l}\text { Surgery. } \\
\text { Died }\end{array}$ & $\begin{array}{l}\text { Anterior and } \\
\text { posterior spina } \\
\text { bifida }\end{array}$ & $\begin{array}{l}\text { Prevertebral cyst } \\
\text { Posterior dermoid } \\
\text { Lumbar MM† }\end{array}$ \\
\hline Guillery (1937) & - & $3 \mathrm{mth}$ & T5 & $\begin{array}{l}\text { Oesophageal } \\
\text { columnar }\end{array}$ & Died & No abnormality & $\begin{array}{l}\text { Posterior medias- } \\
\text { tinal cyst }\end{array}$ \\
\hline Knight et al. (1954) & $\mathbf{M}$ & $1 \mathrm{yr}$ & $\begin{array}{l}\text { T1-6 } \\
\text { IM* }\end{array}$ & Gastrooesophageal & $\begin{array}{l}\text { Resection. } \\
\text { Alive }\end{array}$ & $\begin{array}{l}\text { Vertebral body } \\
\text { defects C7-T7 }\end{array}$ & Nil \\
\hline Rhaney and Barclay (1959) & $\mathbf{M}$ & 1 day & $\begin{array}{l}\text { C } \\
\text { IM* }\end{array}$ & $\begin{array}{l}\text { Gastric, with per- } \\
\text { forated ulcer }\end{array}$ & Died & $\begin{array}{l}\text { Lumbar spina } \\
\text { bifida }\end{array}$ & Lumbar $\mathbf{M M}+$ \\
\hline Németh (1965) & $\mathbf{M}$ & 6 wk & Mid T & Enterogenous & Died & $\begin{array}{l}\text { Bodies cartilagin- } \\
\text { ous }\end{array}$ & Nil \\
\hline Dorsey and Tabrisky (1966) & $\mathbf{M}$ & $18 \mathrm{yr}$ & C7-T1 & Oesophageal & $\begin{array}{l}\text { Resection. } \\
\text { Alive }\end{array}$ & $\begin{array}{l}\text { Defect through } \\
\text { partially fused } \\
\text { bodies C6-T1 }\end{array}$ & $\begin{array}{l}\text { Upper posterior } \\
\text { mediastinal cyst }\end{array}$ \\
\hline Brun and Saldeen (1968) & $\mathbf{M}$ & $2 \mathrm{mth}$ & $\mathbf{T}$ & $\begin{array}{c}\text { Enterogenous + } \\
\text { oesophageal }\end{array}$ & $\begin{array}{l}\text { Surgery. } \\
\text { Died }\end{array}$ & - & Thoracis $\mathbf{M M} \dagger$ \\
\hline Bale (1973) & $\mathbf{F}$ & $5 \mathrm{mth}$ & T2-5 & $\begin{array}{l}\text { Gastroenterogenous } \\
\text { with perforated } \\
\text { ulcer }\end{array}$ & $\begin{array}{l}\text { Surgery. } \\
\text { Died }\end{array}$ & $\begin{array}{l}\text { Vertebral body } \\
\text { defects T1-T6 }\end{array}$ & Nil \\
\hline
\end{tabular}


A.

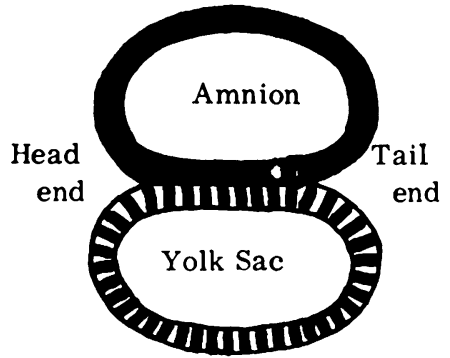

B.

C.
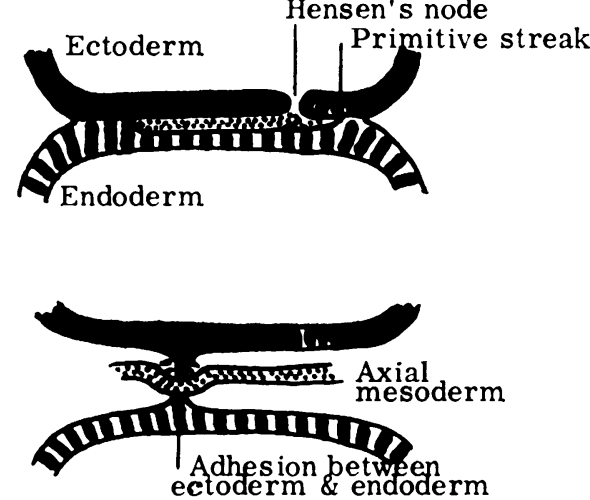

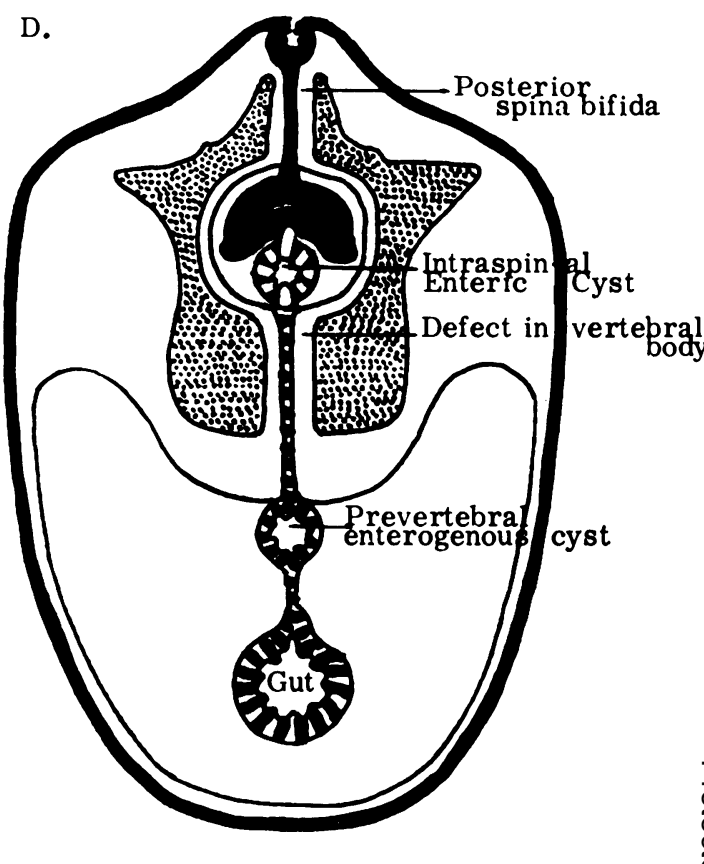

FIG. 7. The two layers of the embryonic disc (A) become separated by mesoderm (B), which is deflected by $\frac{\circ}{6}$ midline adhesion between ectoderm and endoderm $(\mathrm{C})$, resulting in vertebral defects associated with enteric cysts (D).

al., 1954; Németh, 1965; Dorsey and Tabrisky, 1966). Many mediastinal and abdominal enterogenous cysts are also associated with vertebral body anomalies (Fallon et al., 1953; Beardmore and Wiglesworth, 1958), and a triad of intraspinal and prevertebral lesions with vertebral defects has been reported (Korff, 1937; Neuhauser et al., 1958; Dorsey and Tabrisky, 1966). Furthermore, glial tissue has been found in an abdominal enterogenous cyst (Beardmore and Wiglesworth, 1958).

The association of enterogenous cysts with vertebral anomalies suggests an error in embryological development. The theory first propounded by Saunders (1943) and developed by Beardmore and Wiglesworth (1958) and Rhaney and Barclay (1959), satisfactorily accounts for the full triad. These authors postulated a midline ectoendodermal adhesion obstructing the axial mesoderm, and persisting as a neurenteric connection through a vertebral defect.

In the second week of development, the embryo consists of a flat two-layered disc made up of ectoderm in contact with endoderm, between the amnion and yolk sac (Fig. 7A). The most actively growing parts of the ectoderm are Hensen's node and the primitive streak, from which areas a third layer develops between ectoderm and endoderm. This is the mesoderm which is destined to give rise to notochord and vertebrae (Fig. 7B). During the third week, if there were a midline adhesion between ectoderm and endoderm, the axial mesoderm would have to split or detour to pass it (Fig. 7C). This might result in defects in the vertebral bodies, and the adhesion might remain as a post-natal cyst, $\stackrel{3}{.}$. diverticulum, or band between the alimentary tract and the spinal cord (Fig. 7D).

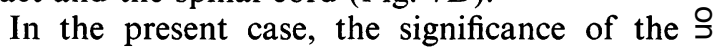
associated vertebral anomalies was not appreci- $\frac{D}{0}$ ated. As a consequence, the filling defect found on the myelogram was ascribed to the bony spur $\mathcal{N}$ seen on the plain film. Such an interpretation $N$ may readily be made, as filling defects due to $\underset{\omega}{N}$ 
bony spurs were demonstrated in five of seven patients with diastematomyelia by Matson et al., (1950).

At surgery the diagnosis may be impossible, as a thick-walled cyst may simulate swollen spinal cord. Also marked inflammatory reaction may obscure the underlying lesion even at necropsy, when cross-sections of the cord (Rhaney and Barclay, 1959) or microscopical examination (as in the present case) may be required before the cyst is revealed. Anomalies of the vertebral bodies should, however, alert one to the possibility of an enterogenous cyst, and the presence of neurological signs may indicate its situation to be intraspinal. If there is no complicating ulcer, curative resection may be possible.

I am grateful to Dr. K. M. de Silva for detailed reports on the radiographs, Dr. A. Kleiber for translations of German papers, and to $\mathrm{Mr}$. H. J. Mitchell for his care in preparation of the sections.

\section{REFERENCES}

Adams, R. D., and Castleman, B. (1960). Case records of the Massachusetts General Hospital. New England Journal of Medicine, 262, 623-627.

Beardmore, H. E., and Wiglesworth, F. W. (1958). Vertebral anomalies and alimentary duplications. Clinical and embryological aspects. Pediatric Clinics of North America, May 1958, 457-474.

Brun, A., and Saldeen, T. (1968). Intraspinal enterogenous cyst. Acta Pathologica et Microbiologica Scandinavica, 73, 191-194.

Bucy, P. C., and Buchanan, D. N. (1935). Teratoma of the spinal cord. Surgery, Gynecology and Obstetrics, 60, 11371144.

Cameron, A. H. (1957). Malformations of the neuro-spinal axis, urogenital tract and foregut in spina bifida attributable to disturbances of the blastopore. Journal of Pathology and Bacteriology, 73, 213-221.

Dorsey, J. F., and Tabrisky, J. (1966). Intraspinal and mediastinal foregut cyst compressing the spinal cord. Report of a case. Journal of Neurosurgery, 24, 562-567.

Fallon, M., Gordon, A. R. G., and Lendrum, A. C. (1954). Mediastinal cysts of fore-gut origin associated with vertebral abnormalities. British Journal of Surgery, 41, 520-533.

Guillery, H. (1937). Eine in die Wirbelsäule eingewachsene mediastinale Zyste (Vorderdarmzyste). Zentralblatt fïr Allgemeine Pathologie und pathologische Anatomie, 69, 4953.

Harriman, D. G. F. (1958). An intraspinal enterogenous cyst. Journal of Pathology and Bacteriology, 75, 413-419.
Harrington, E. S., and Kell, J. F., Jr. (1955). Intraspinal teratoma, with report of a case. Journal of Neuropathology and Experimental Neurology, 14, 214-221.

Hoefnagel, D., Benirschke, K., and Duarte, J. (1962). Teratomatous cysts within the vertebral canal. Observations on the occurrence of sex chromatin. Journal of Neurology, Neurosurgery, and Psychiatry, 25, 159-164.

Knight, G., Griffiths, T., and Williams, I. (1955). Gastrocystoma of the spinal cord. British Journal of Surgery, 42, 635-638.

Korff, H. (1937). Über ein Darmstück in einer Wirbelspalte als Ausdruck einer unvollständigen neurenterischen Verbindung. Virchows Archiv für pathologische Anatomie und für klinische Medizin, 299, 190-202.

Kubie, L. S., and Fulton, J. F. (1928). A clinical and pathological study of two teratomatous cysts of the spinal cord, containing mucus and ciliated cells. Surgery, Gynecology and Obstetrics, 47, 297-311.

Langmaid, C., and Jones, R. (1963). Enterogenous cysts of the spinal cord with associated anomalies. Society of British Neurological Surgeons. 68th Meeting. (Abstract.) Journal of Neurology, Neurosurgery, and Psychiatry, 26, 559.

Masten, M. G. (1940). Teratoma of the spinal cord. Archives of Pathology, 30, 755-761.

Matson, D. D., Woods, R. P., Campbell, J. B., and Ingraham, F. D. (1950). Diastematomyelia (congenital clefts of the spinal cord). Diagnosis and surgical treatment. Pediatrics, 6, 98-112.

Moore, M. T., and Book, M. H. (1966). Congenital cervical ependymal cyst. Report of a case with symptoms precipitated by injury. Journal of Neurosurgery, 24, 558-561.

Németh, K. (1965). Enterogene Zyste des Rückenmarks. Zentralblatt für allgemeine Pathologie und pathologische Anatomie, 108, 196-200.

Neuhauser, E. B. D., Harris, G. B. C., and Berrett, A. (1958). Roentgenographic features of neurenteric cysts. American Journal of Roentgenology, Radium Therapy and Nuclear Medicine, 79, 235-240.

Puussepp, M. (1934). Variété rare de tératome sous-dural de la région cervicale (intestinome). Quadriplégie. Extirpation. Guérison complète. Revue Neurologique, 2, 879-886.

Rand, R. W., and Rand, C. W. (1960). Epidermoids, dermoids and dermal sinuses. Extradural spinal cysts. In Intraspinal Tumors of Childhood, pp. 349-381 and 425-446. By R. W. and C. W. Rand. Thomas: Springfield, Ill.

Rewcastle, N. B., and Francoeur, J. (1964). Teratomatous cysts of the spinal canal. With 'sex chromatin' studies. Archives of Neurology, 11, 91-99.

Rhaney, K., and Barclay, G. P. T. (1959). Enterogenous cysts and congenital diverticula of the alimentary canal with abnormalities of the vertebral column and spinal cord. Journal of Pathology and Bacteriology, 77, 457-471.

Saunders, R. L. deC. H. (1943). Combined anterior and posterior spina bifida in a living neonatal human female. Anatomical Record, 87, 255-278.

Scoville, W. B., Manlapaz, J. S., Otis, R. D., and Cabieses, F. (1963). Intraspinal enterogenous cyst. Journal of Neurosurgery, 20, 704-706.

Small, J. M. (1962). Pre-axial enterogenous cysts. Society of British Neurological Surgeons. 64th Meeting. (Abstract.) Journal of Neurology, Neurosurgery, and Psychiatry, 25, 184. 